\title{
COMPARISON OF ANAEROBIC DIGESTION TECHNOLOGIES: AN ITALIAN CASE STUDY
}

\author{
Giovanni Francini ${ }^{1}$, Marzio Lasagni ${ }^{2}$ and Lidia Lombardi ${ }^{3, *}$ \\ ${ }^{1}$ DICEA - Department of Civil and Environmental Engineering, University of Florence, via Santa Marta 3, 50139 Florence, Italy \\ ${ }^{2}$ AISA IMPIANTI S.p.A., Strada Vicinale dei Mori, località S. Zeno, Arezzo, 52100 Arezzo, Italy \\ ${ }^{3}$ Niccolò Cusano University, via Don Carlo Gnocchi 3, 00166 Rome, Italy
}

Article Info:
Received:
21 December 2018
Revised:
29 January 2020
Accepted:
25 February 2020
Available online:
23 March 2020
Keywords:
Anaerobic digestion
Dry batch process
Wet process
Energy
Economics
$\mathrm{CO}_{2}$

Article Info

21 December 2018

Revised:

Accepted:

25 February 202

23 March 2020

Keywords:

Anaerobic digestion

Wet process

Economics

$\mathrm{CO}_{2}$

\begin{abstract}
The present study focused on a comparison of two technologies applied in the mesophilic anaerobic digestion, namely a conventional wet one and a dry batch one. The considered substrate was the source sorted organic fraction of municipal solid waste (SS-OFMSW) and the input flow rate, for the study case, was $35,000 \mathrm{Mg} /$ year. The analysed systems included the pre-treatment of the SS-OFMSW, anaerobic digestion, upgrading of biogas to biomethane and aerobic post-treatment for the purpose of obtaining compost. The comparison was made by the calculation of three indicators: net present value, total primary energy and $\mathrm{CO}_{2}$ equivalent emissions, with the aim of providing elements for choosing the most appropriate technology for the specific case. The results obtained demonstrated the finding of worse values by the total primary energy indicator for the dry batch technology, providing a saving of approx. $21 \%$ lower compared to the wet one. In terms of $\mathrm{CO}_{2}$ equivalent emissions, the dry batch anaerobic digestion technology provided a better indicator than the wet anaerobic digestion system. Sensitivity analysis revealed the finding of an opposite result only when high specific gas production values were assumed for wet anaerobic digestion, and low specific gas production values for the dry batch technology. From an economic perspective, the results indicated a preference for the dry batch technology due to a higher net present value and a shorter period of return of the investment. This finding was also confirmed by a Monte Carlo uncertainty analysis, showing how the dry batch system featured a $90 \%$ of possibility of achieving a higher economically sustainability versus the wet technology.
\end{abstract}

\section{INTRODUCTION}

The source sorted organic fraction of municipal solid waste (SS-OFMSW) is a highly biodegradable material. Thus, biological processes are the preferred methods for processing and treating SS-OFMSW, allowing subsequent material and/or energy recovery (Righi et al., 2013). Biological processes include treatments such as composting and anaerobic digestion (AD) for biogas production and they account for $95 \%$ of current biological treatment operations for organic waste (Oldfield et al., 2016). Even if composting is an energy intensive process, due to the need for forced aeration, it may provide energy savings $(0.39 \mathrm{~kJ} / \mathrm{kg}$ of produced compost), on a life cycle assessment (LCA) perspective, as a consequence of the avoided chemical fertilisers, with a limited increase of energy consumption compared to landfill (+20\%) (Blengini, 2008). AD is the best option in terms of total greenhouse gas (GHG) emissions when compared with food waste incineration or landfill (Evangelisti et al., 2014).
Today, the installed capacity of anaerobic digestion is fast increasing (Mata-Alvarez et al., 2014). Since 2009, the number of biogas plants in Europe has approximately tripled and reached about 11,000 units at the end of 2016 with an installed electric capacity of 10,000 MW (EBA, 2017).

Italy is also following this trend. In 2016, the municipal solid waste (MSW) disposed in landfills was about 7.4 million Mg, 50\% less than in 2010. Approximately 5.7 million $\mathrm{Mg}$ of MSW are currently processed in biological treatment plants ( $+10 \%$ compared to 2015). About 2 million $\mathrm{Mg}$ are fed to integrated aerobic/anaerobic treatment plants, and about 250,000 $\mathrm{Mg}$ are treated in anaerobic digestion plants. Integrated systems are spreading at the national level, showing an increase of $29 \%$ in the amount of treated waste in the last two years (ISPRA, 2017).

$A D$ processes can be classified according to the total solid (TS) content of the substrate in the reactor. In the wet $A D$, the SS-OFMSW is mixed with water (or other liquid 
streams) to reach a TS content lower than $10-12 \%$, and it is degraded in reactors whose ideal model is the continuous stirred-tank one. In a semi-dry AD (10-20\% of TS) and dry AD (20-40\% of TS) plug-flow or batch reactors are usually used to handle high values of TS (Mata-Alvarez, 2002). The wet $A D$ is well known and suitable for co-digestion with high liquid content waste (such as sewage sludge), thus reducing costs for pumping and mixing systems. However, investment costs remain quite high because of the equipment required for pre-treatments and the considerable amount of process water to be cleaned. Conversely, the dry $A D$ requires minimal pre-treatments and no mixing, reduced reactor volume and process water, but it is characterised by a lower biogas production (Cecchi et al., 2005).

In the last decades, a large number of studies were made about the AD processes and technologies, especially regarding the anaerobic treatment of the SS-OFMSW, its process design aspects and its potential for energy recovery (Chatterjee and Mazumder, 2016). Within this framework, the dry AD represents a well-established technology for the MSW treatment in Europe (Brown and Li, 2013). For this type of $A D$, some studies assessed the influence of the initial TS content of the organic matter in the digester and the related biogas generation (methane yield). Fernandez et al. and Forster-Carneiro et al., for a mesophilic lab-scale $A D$, respectively of OFMSW and food waste, operating in batch mode, evaluated a higher methane production for a process with $20 \%$ of TS rather than $30 \%$ of TS (Fernández et al., 2008; Forster-Carneiro et al., 2008). Zhang and Banks also found that, processing the same organic matter, the methane yield of a wet AD was higher than that of a dry AD (Zhang and Banks, 2013). Numerous studies focused on the operating parameters of food waste $A D$ and on the comparison between different management strategies of MSW, among such AD technologies, have been carried out (Ren et al., 2018). However, to the best of the authors' knowledge, few works are available about the comprehensive comparison between wet and dry AD in terms of environmental impacts, energy and economics. Luning et al. made a comparison between a full-scale dry process (Valorga dry technology) and a wet process, concluding that the choice between the two technologies was highly dependent on the environmental standards of the AD products at the national level (Luning et al., 2003). Colazo et al. estimated the loss of potential biogas production due to the loss of organic matter in the pre-treatment steps of two SS-OFMSW AD facilities (BTA wet and Valorga dry technologies) and the associated environmental burdens of the rejected material disposal. They concluded that the pre-treatments required for the wet process generated a higher amount of rejected materials (161 kg per Mg of OFMSW in the dry case vs. $337 \mathrm{~kg}$ per Mg of OFMSW in the wet case), in which a high amount of organic fraction (about $76 \%$ of the rejected material) is lost and that the incineration disposal for such rejects was more favourable than the landfill disposal (Colazo et al., 2015). Daniel-Gromke et al., measuring the GHG emissions of twelve AD plants of bio-waste, indicated that each plant showed a very different emission rate (Daniel-Gromke et al., 2015). Only Angelonidi and Smith quantified the environmental and eco- nomic performances of eight AD plants of MSW and food waste, among which two technologies based on gas-proof box-shaped reactors working in batch mode at mesophilic temperatures, herein referred to as dry batch $A D$ (Angelonidi and Smith, 2015). They showed how the dry batch technologies had benefits in terms of flexibility over the accepted feedstock, but worse energy and economic indicators. However, at industrial scale, dry batch AD seemed to be an appealing solution for the treatment of the organic fraction resulting from a mechanical sorting process of MSW (Di Maria et al., 2012).

Within this framework, we highlight that a comprehensive comparison of the available $A D$ technologies considering at once environmental implications, energy and economics, and also including pre-treatments, fate of the rejected materials and effective biogas production, was not yet fully reported in previous literature. We believe that such a comparison could help in highlighting benefits and drawbacks of the AD technologies.

Global primary energy consumption grew strongly in 2017, having the fastest growth since 2013 (British Petroleum, 2018). Moreover, the energy sector still depends mostly on fossil fuels whose combustion contributes to greenhouse gas (GHG) emissions (IPCC, 2014). The calculation of GHG emissions from different plants, such as $A D$ plants or composting plants, could help in understanding the impacts and suggesting improvements for emission reduction strategies in the waste sector (Friedrich and Trois, 2016; Marchi et al., 2017). Complementary economic and financial analysis, aimed at evaluating the costs (negative and/or positive) of a product or system during its life (Sullivan et al., 2014), would help to clarify the potential role of waste management plants.

Therefore, the main objective of this study is to analyse two possibilities for the anaerobic treatment of SS-OFMSW - the dry and the wet technologies - looking at the results in terms of costs, primary energy and $\mathrm{CO}_{2}$ equivalent emissions. Specifically, we include within the studied systems the pre-treatments, the disposal of the rejected materials, the biogas exploitation. This type of approach is not so common in the international literature, while it can help in providing elements for choosing the appropriate technologies.

Among the dry AD technologies, the dry batch mesophilic one is selected in particular for its simplicity and ability to treat substrates with high content of dry substance (such as SS-OFMSW), avoiding potential problems related to pumps and stirrers, with expected lower energy consumption. Additionally, the dry batch technology can handle entering substrates containing undesired materials, thus not requiring intensive pre-treatments for the SSOFMSW. As reported by Qian et al. (Qian et al., 2016), in recent years due to these advantages, this type of dry $A D$ has gained enormously in importance in the field of waste treatment. A conventional wet mesophilic technology is considered for comparison. Furthermore, in both the cases, it is assumed to upgrade the produced biogas to biomethane. The entire plants are preliminarily sized for a study case $(35,000 \mathrm{Mg} /$ year).

In the following sections, after the description of the context where the case study is located, the main data 
about mass balances, energy consumptions and economic parameters are reported; then, the evaluation methods are explained; finally, the results are shown according to the selected evaluation methods, also analysing their sensitivity with respect to key parameters.

\subsection{Abbreviations}

AD: Anaerobic digestion

GHG: Greenhouse gas

HRT: Hydraulic retention time

i\%: Rate of return

LCA: Life cycle assessment

LHV: Low heating value

MSW: Municipal solid waste

NPV: Net present value

O\&M: Operation and maintenance

SGP: Specific biogas production

SS-OFMSW: Source sorted organic fraction of municipal solid waste

TPE: Total primary energy

TS: Total solid

TVS: Total volatile solid

W: Water

\subsection{Units}

$1 \mathrm{Mg}=10^{6} \mathrm{~g}$

\section{MATERIALS AND METHODS}

\subsection{Case study}

The analysis is carried out for a study case plant, located in Arezzo, in central Italy. At this industrial site, the company - AISA IMPIANTI S.p.A. - presently operates a mechanical sorting process of mixed MSW, a waste-to-energy plant and a composting plant. The mechanical sorting process consists of a shredder for opening the bags and reducing the size of the mixed MSW, an electromagnet for the extraction of the metals, a rotating drum screen for the separation of the above sieve fraction, mainly composed of dry materials, and the passing sieve fraction, mainly composed of biodegradable humid fraction. The dry flow, characterised by low moisture content (not exceeding 25\%) and rich of materials such as plastics and paper (respectively about $30 \%$ and $25 \%$ of the dry flow), presents rather good fuel properties because of its significant low heating value (LHV), generally higher than $15 \mathrm{MJ} / \mathrm{kg}$ (Di Lonardo et al., 2012). Thus, it is sent to combustion for energy recovery through a moving-grate waste-to-energy plant. On the other hand, the biodegradable humid fraction, characterised by relevant organic matter with moisture content of $40-55 \%$ by weight (Di Lonardo et al., 2012), is processed by an aerobic biological process for biostabilisation through an aerated (turned) windrow. The biological stabilisation and decomposition of this biodegradable humid fraction produce a final stable product, free of pathogens, which can be applied as lining and capping of landfill sites. Additionally, about $23,000 \mathrm{Mg}$ /year of SS-OFMSW are fed to the composting process, also present in the same industrial site. The composting of SS-OFMSW produces a nutrient-rich matter suitable for land application. The amount of SS-
OFMSW is constantly increasing year after year thanks to the implementation of improved separate collection methodologies. In Arezzo, in 2017, the separate waste collection increased by 15\% with respect to the year 2015 (Agenzia Regionale Recupero Risorse S.p.A., 2017). Thus, AISA IMPIANTI S.p.A. is planning to build an AD plant able to treat $35,000 \mathrm{Mg} /$ year upstream of the composting process; their aim is to evaluate the best technology choice for their specific case.

Thus, the different technical possibilities for processing $35,000 \mathrm{Mg} /$ year of SS-OFMSW by anaerobic digestion producing biogas, further upgraded to biomethane, are compared from the economic point of view and by performing balances of $\mathrm{CO}_{2}$ equivalent emissions and primary energy, also comparing the results with those calculated for conventional aerobic composting. In order to carry out such analyses, a preliminary modelling of the two alternative processes is provided in the following paragraphs.

\subsection{Wet anaerobic digestion process}

In order to process $35,000 \mathrm{Mg} /$ year, the plant is fed by a steady flow of about $96 \mathrm{Mg} /$ day of SS-OFMSW. The SSOFMSW entering the plant is originated from door-to-door collection within Arezzo Municipality. The observed SSOFMSW still presents a large quantity of undesired materials. However, it is consistent with other common cases in Italy, as reported in Micolucci et al. (Micolucci et al., 2018). Thus, even if the entering material comes from the source sorted collection system, the quality is still not pure, and about $30 \%$ of undesired materials (mainly plastics, glasses, metals, inert) must be removed in a pre-treatment step, which uses a pulper. During such a pre-treatment process, also part of the biodegradable fraction is, unfortunately, removed. This amount is estimated as an additional $16 \%$, with respect to the undesired materials (Khoshnevisan et al., 2018), clearly representing a loss of potential biogas production.

Thus, about $61 \mathrm{Mg} /$ day of pre-treated flow is directed to the mesophilic anaerobic digestion. Table 1 reports the estimated mass flow rates before and after the pre-treatment step and their characteristics in terms of TS, total volatile solid (TVS) and water (W).

Assuming that the wet anaerobic reactor operates with a TS content equal to $10 \%$, the amount of required water for dilution is calculated, resulting equal to about $98 \mathrm{Mg} /$ day (or $98 \mathrm{~m}^{3} /$ day): this amount can be obtained downstream of the wastewater treatment of the process liquid effluent. Providing that the hydraulic retention time (HRT) equals to 20 days, the required volume for the digester is about 4,000 $\mathrm{m}^{3}$.

According to Mata-Alvarez (Mata-Alvarez, 2002), the generated biogas volumetric composition is $60 \% \mathrm{CH}_{4}, 38 \%$

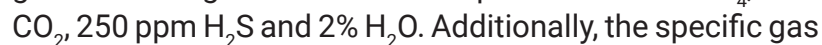
production (SGP) is estimated to be $0.589 \mathrm{Nm}^{3}$ of produced biogas per $\mathrm{kg}$ of TVS supplied to the reactor (Mata-Alvarez, 2002), obtaining about $95 \mathrm{Nm}^{3}$ of biogas per $\mathrm{Mg}$ of SS-OFMSW entering the plant (i.e. referring to the entering amount before the pre-treatment). The biogas daily flow of about $9,116 \mathrm{Nm}^{3} /$ day is sent for upgrading, producing $5,526 \mathrm{Nm}^{3} /$ day of biomethane. For the upgrading process, 
a biomethane purity ( $\mathrm{CH}_{4}$ content) equal to $97 \%$ and methane losses equal to $2 \%$ (Sun et al., 2015) are considered.

The produced digestate, with $3.5 \% \mathrm{TS}$, is sent to a centrifuge for the solid-liquid separation step, producing about $16 \mathrm{Mg} /$ day of solid part (25\% TS) and $133 \mathrm{Mg} /$ day of liquid part. The liquid part, rich in organic compounds and nutrients, is sent to the wastewater treatment plant (provided that it is built in the same site), and, after this process, 98 $\mathrm{Mg} /$ day are recirculated for the digester substrate dilution. The solid fraction is sent for aerobic composting with a specific compost production rate of $39 \%$ of the entering matter (Boldrin et al., 2010; Saer et al., 2013). Usually, to ensure the proper aeration during the composting process, lignocellulosic wastes are added to the digestate as structuring materials. However, lignocellulosic wastes are not considered within the studied system, given that they would be composted anyway (with or without the digestate).

\subsubsection{Energy consumption}

For the wet $A D$ process, electricity and fuel consumptions for processing and handling the material are considered. Electricity consumption for the pre-treatment and the anaerobic digestion phase is set at $55 \mathrm{kWh}$ per $\mathrm{Mg}$ of processed material (IPPC, 2006). For the solid/liquid separation process, an average consumption of $45 \mathrm{kWh}$ per Mg of dry matter is estimated (Masotti, 2011), while for the composting of the solid fraction, discharged by the centrifuge, the estimation is $20 \mathrm{kWh} / \mathrm{Mg}$ (Torretta et al., 2014). A consumption of $0.65 \mathrm{kWh}$ is assumed per each $\mathrm{m}^{3}$ of liquid effluent treated in a wastewater process, based on primary and secondary treatments (Campanelli et al., 2013). At the time of writing, the biogas upgrading technology is not yet defined, and thus an average preliminary value of electricity consumption equal to $0.22 \mathrm{kWh} / \mathrm{Nm}^{3}$ of entering biogas is estimated (Sun et al., 2015).

Diesel fuel is consumed by the operating machines used to feed the pre-treatment section as well as to the handling and movement of the heaps for the composting plant. The diesel consumption is estimated $0.78 \mathrm{l} / \mathrm{Mg}$ according to the experience of AISA IMPIANTI S.p.A.. Also, the diesel consumption for the transportation of the pre-treatment discards to landfills is considered, assuming a transportation distance of $100 \mathrm{~km}$ and a freight lorry transport with 26 $\mathrm{Mg}$ of capacity able to cover $2.8 \mathrm{~km}$ using one litre of diesel (Ministero delle Infrastrutture e dei Trasporti, 2009).

\subsubsection{Costs}

Investment, mortgage, operation and maintenance (O\&M) costs are considered. Revenues from the SS-OFMSW gate fee and biomethane selling are accounted for. For the wet $A D$ process, the investment cost for the construction of the anaerobic digestion plant (pre-treatment, anaerobic digester, wastewater treatment, biogas upgrading and additional aerobic post-treatment) amounts to approximately $€ 11,399,900$, of which $61 \%$ is financed with an interest rate of $3.5 \%$ for 10 years (the resulting mortgage is thus equal to $839,071 € /$ year). Table 2 summarises the annual O\&M costs and revenues. With reference to typical Italian market conditions, the diesel price, the waste landfilling cost and the gate fee specific revenue are respectively $1.51 €$ per litres, $90 €$ per Mg of waste and $62 €$ per Mg of SS-OFMSW treated. For AISA IMPIANTI S.p.A., the average electricity price is $63 € / \mathrm{MWh}$ because the plant (see the waste-to-energy plant) is a self-producer of electric energy. According to the Italian incentive scheme for biomethane injection into the natural gas grid (GME-Gestore Mercati Energetici, 2018) and its use in the field of transportation (Ministero dello Sviluppo Economico, 2018), the biomethane sale revenues are, respectively, equal to $22.738 € / \mathrm{MWh}$ and $375 €$ / $\mathrm{CIC}$ (where $1 \mathrm{CIC}$ is equal to $5 \mathrm{Gcal}$ of biomethane). After 10 years, the incentive due to the use of biomethane in the transport sector $(\mathrm{CIC})$ will be reduced by $85 \%$.

\subsection{Dry batch anaerobic digestion process}

For the dry process, we examine the technology based on gas-proof box-shaped reactors, operating in batch mode at mesophilic temperatures. The amount of SS-OFMSW entering the plant daily is the same as in the previous case ( $96 \mathrm{Mg} /$ day). Also, the characterisation in terms of TS, TVS and $\mathrm{W}$ is the same as that reported in the first column of Table 1. However, in this second case, only a light pre-treatment is considered, based on waste simple shredding and producing $3 \%$ of water losses (to be processed in a wastewater treatment plant). Therefore, the stream fed to anaerobic digestion is about $94 \mathrm{Mg} /$ day, according to the details reported in Table 3. In order to promote the anaerobic degradation, part of the digestate must be recirculated into the batch reactor as inoculum, in the ratio 1:1 with the fresh waste (Patinvoh, 2017). Thus, the mixture entering into the batch anaerobic digestion reactor is $188 \mathrm{Mg} /$ day.

The volume of each batch reactor is $1092 \mathrm{~m}^{3}$ and it can be filled up to a maximum height of $4 \mathrm{~m}$. Therefore, the volume of the material inside the reactor can be $780 \mathrm{~m}^{3}$ max-

TABLE 1: Entering flows and their characteristics before and after the pre-treatment step in the wet technology.

\begin{tabular}{c|ccccc} 
& \multicolumn{2}{c}{ SS-OFMSW } & SS-OFMSW after pre-treatment \\
\hline TS & [weight \%] & [Mg/day] & [weight \%] & [Mg/day] \\
\hline TVS & 26 & 25 & 26 & 16 \\
\hline W & 74 & 21 & $97 *$ & 15 \\
\hline
\end{tabular}

* as percentage of TS

TABLE 2: Summary of O\&M costs in the case of the wet technology.

\begin{tabular}{|c|c|c|c|}
\hline \multicolumn{2}{|c|}{ Costs [€/year] } & \multicolumn{2}{|c|}{ Revenues [ $€ /$ year] } \\
\hline Staff & 360,000 & Gate fee & $2,170,000$ \\
\hline Maintenance & 348,560 & Biomethane & $1,729,741$ \\
\hline Diesel & 74,274 & Biomethane * & 628,373 \\
\hline Electricity & 182,180 & - & - \\
\hline Disposal costs & $1,134,000$ & - & - \\
\hline Other expenses & 300,559 & - & - \\
\hline Total costs & $2,325,299$ & Total revenues & $3,899,741$ \\
\hline- & - & Total revenues * & $2,798,373$ \\
\hline
\end{tabular}

* from the $11^{\text {th }}$ year 
imum, that is about $500 \mathrm{Mg}$ of material loaded inside the reactor, assuming $0.7 \mathrm{Mg} / \mathrm{m}^{3}$ of density for the SS-OFMSW. If we consider a process duration of 30 days, the number of batch reactors required to process the entering SS-OFMSW is equal to 10 .

According to Neri et al. (Neri et al., 2018), the generated biogas volumetric composition is the same as in the previous case: $60 \% \mathrm{CH}_{4}, 38 \% \mathrm{CO}_{2}, 250 \mathrm{ppm} \mathrm{H}_{2} \mathrm{~S}$ and $2 \% \mathrm{H}_{2} \mathrm{O}$. Furthermore, a precautionary SGP equal to $0.345 \mathrm{Nm}^{3}$ of produced biogas per $\mathrm{kg}$ of TVS supplied to the reactor (Nagao et al., 2012) is considered, resulting in about $75 \mathrm{Nm}^{3}$ of biogas produced per Mg of SS-OFMSW entering the plant (i.e. before the pre-treatment). The daily flow of dry biogas is actually about $7,204 \mathrm{Nm}^{3} /$ day. Biogas is then sent for upgrading, producing $4,380 \mathrm{Nm}^{3}$ /day of biomethane. For the upgrading process, a biomethane purity $\left(\mathrm{CH}_{4}\right.$ content) equal to $97 \%$ and methane losses equal to $2 \%$ (Sun et al., 2015) are assumed.

For the dry AD process, the produced digestate is about $179 \mathrm{Mg} /$ day, of which $94 \mathrm{Mg} /$ day is recirculated back to the reactor as inoculum. The remaining $85 \mathrm{Mg} /$ day is sent for aerobic composting, where, after the biostabilisation, a mechanical treatment is applied to remove undesired materials (compost refining), thus generating some solid discards. The residues are therefore less than in the wet case (about $30 \%$ of the stream entering the plant), without significant losses of organic matter during the overall processes. For this reason, the discards are composed mainly of plastics, glasses, metals and inert. For the composting process of the digestate, the same specific compost production rate of $39 \%$ of the entering matter (Boldrin et al., 2010; Saer et al., 2013) is used. Also, in this case lignocellulosic wastes are required; however, they would be composted anyway (with or without the digestate) and therefore they are not included within the studied system.

\subsubsection{Energy consumption}

Electricity and fuel consumptions for processing and handling the material are included also in this case. The estimated electricity consumption for the light pre-treatment and the anaerobic digestion phase is now set at 30 kWh per Mg of processed material (Gunatilake, 2016). The presumed consumption for the composting section is 20 $\mathrm{kWh} / \mathrm{Mg}$ (Torretta et al., 2014). The same consumption of $0.65 \mathrm{kWh}$ is assumed per each $\mathrm{m}^{3}$ of liquid effluent treated in a wastewater treatment process (Campanelli et al., 2013), yet, in this case, we assume the process to be outside the plant site. For the biogas upgrading, the same average value of electricity consumption equal to $0.22 \mathrm{kWh} /$ $\mathrm{Nm}^{3}$ of entering biogas is estimated (Sun et al., 2015).

The assumed diesel consumption for the light pre-treatment section and the composting process is equal to 0.78 $\mathrm{l} / \mathrm{Mg}$. The transportation distances of the compost refining discards to landfill and of the liquid effluent to the wastewater treatment plant are here presumed to be $100 \mathrm{~km}$.

\subsubsection{Costs}

Investment, mortgage, O\&M costs are also estimated for this second case study together with the revenues from the SS-OFMSW gate fee and biomethane selling.
The investment cost for the construction of the anaerobic digestion plant (light pre-treatment, anaerobic digesters, biogas upgrading and additional aerobic post-treatment) amounts to approximately $€ 9,379,500$, of which $53 \%$ is financed with a rate of interest of $3.5 \%$ for 10 years (the resulting mortgage is equal to 596,135 €/year). Table 4 summarises the annual $0 \& \mathrm{M}$ costs and revenues. The specific costs and revenues are the same as in the wet case.

\subsection{Evaluation methods}

The two different technical alternatives are evaluated through a preliminary economic analysis and balances of energy and $\mathrm{CO}_{2}$ equivalent emissions.

By accepting the estimated costs, the discounted cash flow analysis is calculated through the net present value (NPV) method (Equation 1). This analysis is conducted by subtracting the present values of cash outflows (including initial cost) from the present values of cash inflows over a period of 20 years. The cash flow for each year is first calculated; then, the present value of each one of them is estimated by discounting its future value at a periodic rate of return (i\%), here established to be equal to $6 \%$, according to the data provided by AISA IMPIANTI S.p.A. From the costs reported in Tables 2 and 4, the annual balance can be calculated for both the cases.

$N P V(i, N)=\sum_{t=1}^{N} \frac{C F}{(1+i)^{t}}$

where $\mathrm{i}$ is the rate of return, $\mathrm{N}$ is the total number of periods (20 years), $t$ is the period ( 1 year), and CF is the annual cash flow [€/year].

The energy balance is carried out by considering the consumption of electricity and fuels and the energy pro-

TABLE 3: Entering flows and their characteristics before and after the pre-treatment step in the dry batch technology.

\begin{tabular}{c:c|ccc} 
& \multicolumn{2}{c}{ SS-OFMSW } & \multicolumn{2}{c}{ SS-OFMSW after pre-treatment } \\
\hline & [weight \%] & [Mg/day] & [weight \%] & [Mg/day] \\
\hline TS & 26 & 25 & 27 & 25 \\
\hline TVS & $84^{*}$ & 21 & $84^{*}$ & 21 \\
\hline W & 74 & 71 & 73 & 69 \\
\hline
\end{tabular}

* as percentage of TS

TABLE 4: Summary of O\&M costs in the case of the dry batch technology.

\begin{tabular}{|c|c|c|c|}
\hline \multicolumn{2}{|c|}{ Costs [€/year] } & \multicolumn{2}{|c|}{ Revenues [ $€ /$ year] } \\
\hline Staff & 360,000 & Gate fee & $2,170,000$ \\
\hline Maintenance & 286,785 & Biomethane & $1,370,921$ \\
\hline Diesel & 101,394 & Biomethane * & 498,022 \\
\hline Electricity & 128,558 & - & - \\
\hline Disposal costs & 952,560 & - & - \\
\hline Other expenses & 247,291 & - & - \\
\hline Total costs & $2,076,588$ & Total revenues & $3,540,921$ \\
\hline- & - & Total revenues * & $2,668,022$ \\
\hline
\end{tabular}

* from the $11^{\text {th }}$ year 
duced in the form of biomethane from the anaerobic digestion. In this study, as energy indicator, the total primary energy (TPE) is considered because it accounts for different types of energy, being defined as the energy potential presented by energy flows in their natural form. To convert the electric energy to primary energy, an average efficiency value equal to 0.41 (D.Lgs $192 / 2005,2005$ ) is considered, in accordance with the common practice for all Italian cases. For the fuels, primary energy is calculated on the basis of the LHV, respectively assuming $42,900 \mathrm{~kJ} / \mathrm{kg}$ for diesel and to $35,860 \mathrm{~kJ} / \mathrm{Nm}^{3}$ for biomethane.

The $\mathrm{CO}_{2}$ equivalent emissions, calculated according to the method reported in IPCC Synthesis Report (IPCC, 2014), provide an environmental indicator of the human activities impact on the global climate (Wiedmann and Minx, 2007). For the $\mathrm{CO}_{2}$ balance, the following contributions are considered: emissions due to the production of the required electricity; emissions due to the production of the required fuels and their combustion; emissions of $\mathrm{CH}_{4}$ losses from the upgrading process; emissions from the landfilling of the separated discards and wastewater treatment; avoided emissions for the production and combustion of natural gas displaced by biomethane; and avoided emissions from the compost use. The adopted values for the specific emissions of each process are reported in Table 5 .

The $\mathrm{CO}_{2}$ equivalent emissions deriving from the diesel combustion are calculated through the stoichiometric factor equal to $3.67 \mathrm{kgCO}_{2} / \mathrm{kgC}$. Assuming a carbon content in the diesel fuel equal to $0.86 \mathrm{kgC} / \mathrm{kgDiesel}$ and a diesel density equal to $0.85 \mathrm{~kg} / \mathrm{l}$, for each litre of burnt diesel the $\mathrm{CO}_{2}$ emissions result equal to $2.69 \mathrm{kgCO}_{2} / \mathrm{l}$. The emissions of $\mathrm{CO}_{2}$ deriving from the natural gas combustion are calculated through the stoichiometric factor equal to $2.75 \mathrm{kgCO}_{2} /$ $\mathrm{kgCH}_{4}$. The avoided emissions for natural gas production and the emissions deriving from diesel production, final disposal of residues to landfill and wastewater treatment are retrieved from Ecoinvent 3.0 (Wernet et al., 2016).

For both the TPE and $\mathrm{CO}_{2}$ balances, the process based on the direct composting of the same amount $(35,000 \mathrm{Mg} /$ year) of the SS-OFMSW is included in the comparison considering the following consumptions: $20 \mathrm{kWh} / \mathrm{Mg}$ of electricity (Torretta et al., 2014); $0.78 \mathrm{l} / \mathrm{Mg}$ of diesel according to the experience of AISA IMPIANTI S.p.A.. The compost production rate is assumed to be $39 \%$ of the entering mat-

TABLE 5: Assumed specific $\mathrm{CO}_{2}$ equivalent emissions (avoided emissions have negative values).

\begin{tabular}{|c|c|c|c|}
\hline Process & Unit & Value & Source \\
\hline Electricity & $\mathrm{kgCO}_{2} / \mathrm{kWh}$ & 0.318 & (ISPRA, 2018) \\
\hline Diesel production & $\mathrm{kgCO}_{2} / \mathrm{l}$ & 0.50 & Ecoinvent 3.0 \\
\hline Diesel combustion & $\mathrm{kgCO}_{2} / \mathrm{l}$ & 2.69 & Calculated \\
\hline Methane losses & $\mathrm{kgCO}_{2} / \mathrm{kgCH}_{4}$ & 28 & (IPCC, 2014) \\
\hline Landfill discards & $\mathrm{kgCO}_{2} / \mathrm{kg}$ & 0.502 & Ecoinvent 3.0 \\
\hline Natural gas production & $\mathrm{kgCO}_{2} / \mathrm{Nm}^{3}$ & -0.21 & Ecoinvent 3.0 \\
\hline Natural gas combustion & $\mathrm{kgCO}_{2} / \mathrm{kgCH}_{4}$ & -2.75 & Calculated \\
\hline Compost use & $\mathrm{kgCO}_{2} / \mathrm{Mg}$ & -69 & (Boldrin et al., 2010) \\
\hline Wastewater treatment & $\mathrm{kgCO}_{2} / \mathrm{m}^{3}$ & 0.385 & Ecoinvent 3.0 \\
\hline
\end{tabular}

ter (Boldrin et al., 2010; Saer et al., 2013). Residues from compost mechanical refinement are then sent to landfill, considering a transportation distance of $100 \mathrm{~km}$.

\section{RESULTS AND DISCUSSION}

For the considered case study, the results are reported in the following paragraphs showing the economic analysis, the balances of TPE as well as the $\mathrm{CO}_{2}$ equivalent emissions.

\subsection{Economic analysis results}

Figure 1 shows the discounted cash flow trends over the considered time for the wet and dry batch technologies. Based on the theory of finance (Sullivan et al., 2014) and by comparing two types of investment, the process that shows the highest NPV is certainly preferable. In this instance, the discounted cash flow analysis result is more favourable for the dry batch case; at the same time, the NPV is higher.

For the first 10 years, the simple annual balances obtained for the wet and dry batch technologies (easily calculable from Tables 2 and 4) are both positive (net profit) and equal to $€ 1,500,168$ and $€ 1,464,333$, respectively. From the $11^{\text {th }}$ year, the net cash flow of the wet technology becomes significantly lower than the dry batch one, thus confirming a better economic performance of the dry batch case, which has a return of the investment of about 10 years (vs. about 19 years for the wet case). In this case study, the dry batch $A D$ technology has a lower biomethane revenue; however, the lower costs for electricity and waste disposal to landfill provide a higher NPV than in the wet AD case.

\subsection{Energy balance results}

Table 6 shows the contributions to the TPE balance for the composting, the dry batch anaerobic digestion and the wet anaerobic digestion. Quite obviously, the two anaerobic digestion processes provide much better performances (negative values, meaning savings) than the composting case. This result is due to the energy recovery, in terms of biomethane. The dry batch technology provides lower savings of energy because of the lower production of biomethane. Though, at the same time, the energy required for the process - especially the pre-treatments and wastewater treatment - is also lower. Considering the overall anaerobic digestion process contribution, the dry batch AD technology requires $42 \%$ of primary energy less than the wet one. However, for the dry batch technology, the expected biomethane production is lower. This also means that its upgrading energy balance (electricity requirement + biomethane energy) gives smaller negative contribution (21\%) than in the wet system. Also, the consumptions for the aerobic biostabilisation process are larger for the dry batch technology (300\%) because of the larger amount of composted digestate

Overall, for this case study, the TPE balance is worse in the dry batch case in comparison to the wet process, with savings lower by about $21 \%$. The result is also in agreement with the assessment made by Angelonidi and Smith (Angelonidi and Smith, 2015). 


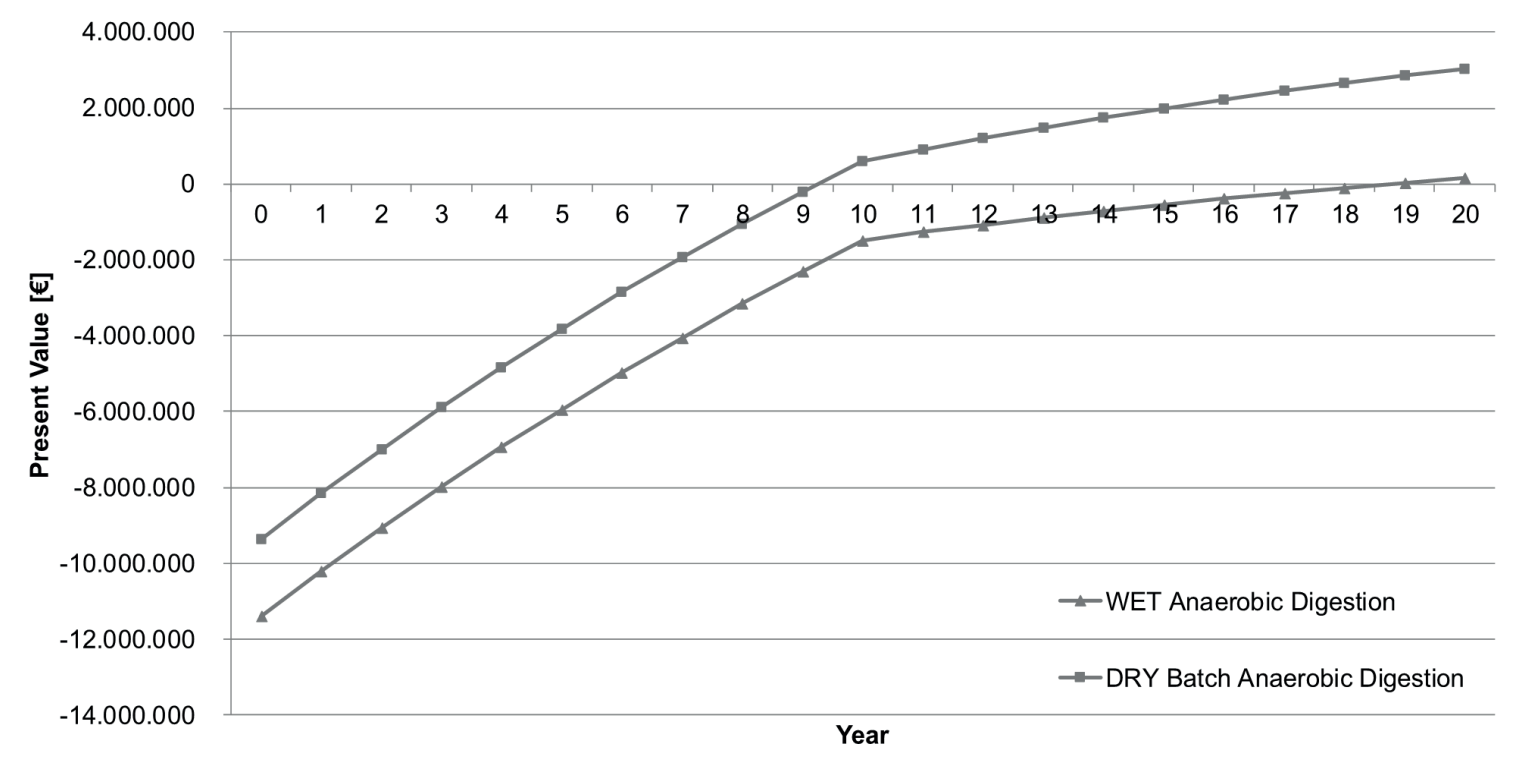

FIGURE 1: Discounted cash flow analysis for the wet and dry technologies.

\section{$3.3 \mathrm{CO}_{2}$ balance results}

Table 7 shows the contributions to the $\mathrm{CO}_{2}$ balance for the composting, the dry batch anaerobic digestion and the wet anaerobic digestion.

For all the cases, the balances are positive because the positive emissions are higher than the avoided (negative) ones. This result is also found in other case studies (Daniel-Gromke et al., 2015). The results are dominated by the high contribution to the $\mathrm{CO}_{2}$ balance deriving from the landfilling of large amount of residue. However, in both the anaerobic digestion cases, the balance is better than in the composting case (which is characterised only by the avoided effects from compost usage) thanks to the avoided emissions for the biomethane production.

The use of compost in the dry batch AD technology gives greater negative contribution than in the wet case $(-249 \%)$, but the biomethane production provides less avoided emissions (21\%). In general, the total contribution of the $A D$ phase in the dry batch system gives $-43 \%$ $\mathrm{Mg} \mathrm{CO}_{2} /$ year than in the wet AD. The total $\mathrm{CO}_{2}$ emissions are lower in the dry batch $A D$ case $(-24 \%)$ because of the moderated impacts of the anaerobic digestion energy re- quirements, the upgrading operations and the waste disposal to landfill.

The opposite results of the $\mathrm{CO}_{2}$ balance and TPE balance are mainly due to the $\mathrm{CO}_{2}$ contributions not related to energy input/output, namely compost avoided emissions, methane losses and emissions from landfill discards.

\subsection{Sensitivity analysis}

In the field of AD processes, data on SGPs are by nature subject to variability. SGP values directly affect the production of biogas/biomethane, influencing the main contributions to the previously shown balances (energy, $\mathrm{CO}_{2}$ and economics). Thus, a sensitivity analysis with respect to this parameter is necessary, in order to better evaluate the effective contribution of energy recovery in terms of biomethane. For this reason, the reference SGPs of both wet and dry $A D$ technologies, respectively equal to 0.589 and $0.345 \mathrm{Nm}^{3}$ of produced biogas per $\mathrm{kg}$ of TVS (Table 8), are changed. According to the SGP values retrieved from literature (Angelonidi and Smith, 2015; Cecchi et al., 2005), a variation of $+/-20 \%$ is considered with respect to the used reference values.

TABLE 6: Total primary energy comparison of the considered technologies.

\begin{tabular}{|c|c|c|c|c|}
\hline & & $\begin{array}{l}\text { Composting } \\
\text { [MWh/year] }\end{array}$ & $\begin{array}{l}\text { Dry batch AD } \\
\text { [MWh/year] }\end{array}$ & $\begin{array}{c}\text { Wet AD } \\
\text { [MWh/year] }\end{array}$ \\
\hline \multirow[t]{4}{*}{ Anaerobic digestion process } & Electricity pre-treatments $+A D$ & - & 1,050 & 1,925 \\
\hline & Electricity centrifugation & - & - & 86 \\
\hline & Electricity wastewater treatment & - & 0.5 & 31 \\
\hline & Diesel & - & 287 & 277 \\
\hline \multirow[t]{2}{*}{ Aerobic biostabilisation } & Electricity & 488 & 410 & 117 \\
\hline & Diesel & 277 & 246 & 46 \\
\hline \multirow[t]{2}{*}{ Upgrading } & Electricity & - & 580 & 732 \\
\hline & Biomethane energy & - & $-15,924$ & $-20,092$ \\
\hline Transportation to landfill & Diesel & 147 & 147 & 175 \\
\hline Total primary energy & Energy & 912 & $-13,203$ & $-16,702$ \\
\hline
\end{tabular}


TABLE 7: $\mathrm{CO}_{2}$ emission comparison of the considered technologies.

\begin{tabular}{|c|c|c|c|c|}
\hline & & $\begin{array}{c}\text { Composting } \\
{\left[\mathrm{Mg} \mathrm{CO}_{2} / \text { year] }\right.}\end{array}$ & $\begin{array}{l}\text { Dry batch AD } \\
{\left[\mathrm{Mg} \mathrm{CO}_{2} / \text { year] }\right.}\end{array}$ & $\begin{array}{c}\text { Wet AD } \\
{\left[\mathrm{Mg} \mathrm{CO}_{2} / \text { year }\right.}\end{array}$ \\
\hline \multirow[t]{4}{*}{ Anaerobic digestion process } & Electricity pre-treatments + AD & - & 334 & 612 \\
\hline & Electricity centrifugation & - & - & 27 \\
\hline & Wastewater treatment & - & 0.3 & 19 \\
\hline & Diesel & - & 91 & 87 \\
\hline \multirow[t]{3}{*}{ Aerobic biostabilisation } & Electricity & 155 & 130 & 37 \\
\hline & Diesel & 87 & 77 & 15 \\
\hline & Use of compost & -657 & -551 & -158 \\
\hline \multirow[t]{3}{*}{ Upgrading } & Electricity & - & 184 & 233 \\
\hline & Biomethane production & - & $-3,370$ & $-4,252$ \\
\hline & Methane losses & - & 633 & 798 \\
\hline \multirow[t]{2}{*}{ Landfilling of process residues } & Diesel & 46 & 46 & 55 \\
\hline & Waste landfilling & 5,313 & 5,313 & 6,325 \\
\hline Total emissions & $\mathrm{CO}_{2}$ & 4,944 & 2,887 & 3,798 \\
\hline
\end{tabular}

TABLE 8: SGP variation for the wet and dry batch AD technologies.

\begin{tabular}{|c|c|c|c|c|c|c|}
\hline & & $-20 \%$ & $-10 \%$ & Ref & $+10 \%$ & $+20 \%$ \\
\hline \multirow[t]{2}{*}{ Wet AD } & $\mathrm{SGP}\left[\mathrm{Nm}^{3} / \mathrm{kg} \mathrm{TVS}\right]$ & 0.471 & 0.530 & 0.589 & 0.648 & 0.707 \\
\hline & SGP $\left[\mathrm{Nm}^{3} / \mathrm{Mg}\right.$ SS-OFMSW] & 75 & 85 & 95 & 105 & 115 \\
\hline \multirow[t]{2}{*}{ Dry batch AD } & $\mathrm{SGP}\left[\mathrm{Nm}^{3} / \mathrm{kg} \mathrm{TVS}\right]$ & 0.276 & 0.311 & 0.345 & 0.380 & 0.414 \\
\hline & SGP $\left[\mathrm{Nm}^{3} / \mathrm{Mg}\right.$ SS-OFMSW] & 60 & 67 & 75 & 83 & 90 \\
\hline
\end{tabular}

The TPE and the total $\mathrm{CO}_{2}$ equivalent emissions of the wet and dry batch $A D$ systems are recalculated according to the SGP variation. The modified results of TPE and $\mathrm{CO}_{2}$ equivalent emission balances are detailed respectively in Table 9 and Figure 2.

In Table 9, "TPE wet" is the total primary energy indicator calculated for the wet case, while "TPE dry" is the total primary energy indicator calculated for the dry batch case.

Even if we consider a dry batch AD process with high performances, the "TPE dry" is better than the "TPE wet" only when the wet AD has quite low SGP values. So, in general, we expect that the TPE indicator is almost always better for the wet case.

The SGP variation corresponds to different energy yields, also leading to the modification of the $\mathrm{CO}_{2}$ balance. In Figure 2, the modification of the $\mathrm{CO}_{2}$ balance is reported as the difference between the $\mathrm{CO}_{2}$ emission $\left(\Delta \mathrm{CO}_{2}\right)$ values calculated for the two considered systems (Equation 2):

$\triangle \mathrm{CO}_{2}=\mathrm{CO}_{2}$ Wet $A D^{-} \mathrm{CO}_{2}$ Dry $A D$

In Figure 2, the $\Delta \mathrm{CO}_{2}$ variation is reported as a function of the different SGPs of the two technologies.

From Figure 2, it is observed that $\Delta \mathrm{CO}_{2}$ is lower than zero (the black part of the graph) in the $2 \%$ of the cases: for these cases the $\mathrm{CO}_{2}$ balance of the wet $\mathrm{AD}$ is better (lower) than the $\mathrm{CO}_{2}$ balance of the dry AD. This only happens when high SGP values are assumed for the wet $A D$ and low SGP values for the dry batch $A D$.

For the rest of the cases (98\%), the $\mathrm{CO}_{2}$ balance of the wet $A D$ technology is worse (higher) than the $\mathrm{CO}_{2}$ balance of the dry $A D$ one.
The sensitivity analysis for the $\mathrm{CO}_{2}$ balance shows that the conclusions are poorly influenced by the estimated values for the SGP, confirming that, in this case study, the $\mathrm{CO}_{2}$ balance is in general better for the dry batch technology.

The sensitivity of the economic results to the SGP value variation is also investigated by a Monte Carlo uncertainty analysis. For both wet and dry batch AD cases, 1000 random values of SGP are generated between the maximum and minimum values reported in Table 8 . For each SGP value, the NPV is recalculated. When the NPV is negative, the initial investment is not justified.

For the 1000 random SGP values generated for dry batch AD, the NPV remains positive (Figure $3 b$ ).

On the contrary, for the 1000 random SGP values generated for the wet $A D, 50 \%$ of the NPV values are negative, meaning that the investment is not economically sustainable in $50 \%$ of the cases (Figure $3 a$ ).

Finally, the i-th NPV modification is calculated as the difference between the i-th NPV $(\triangle N P V i)$ values calculated for the two compared cases (Equation 3$)$ :

$\triangle N P V i=N P V i$ Dry $A D-N P V i$ Wet $A D$

quantifies the difference between the times that the NPV output of the dry batch AD system is higher than that of the wet $A D$ system.

TABLE 9: TPE variation according to different SGPs of the considered $\mathrm{AD}$ technologies.

\begin{tabular}{c|cccc:c:c} 
& $-\mathbf{2 0} \%$ & $-\mathbf{1 0} \%$ & Ref & $\mathbf{+ 1 0 \%}$ & $\mathbf{+ 2 0 \%}$ \\
\hline TPE wet [MWh/year] & $-12,722$ & $-14,712$ & $-16,702$ & $-18,692$ & $-20,683$ \\
TPE dry [MWh/year] & $-10,117$ & $-11,683$ & $-13,203$ & $-14,769$ & $-16,290$ \\
\hline
\end{tabular}




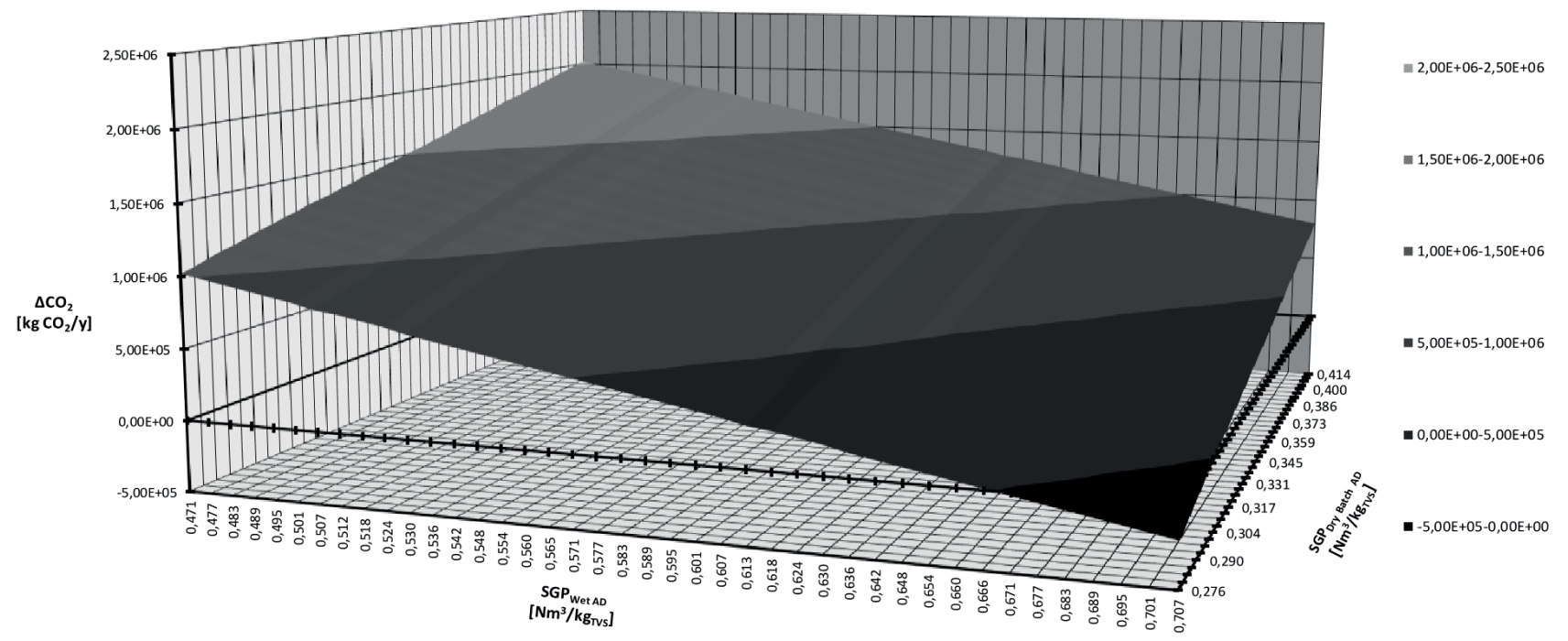

FIGURE 2: $\mathrm{CO}_{2}$ balance variation according to different SGPs of the considered AD technologies.

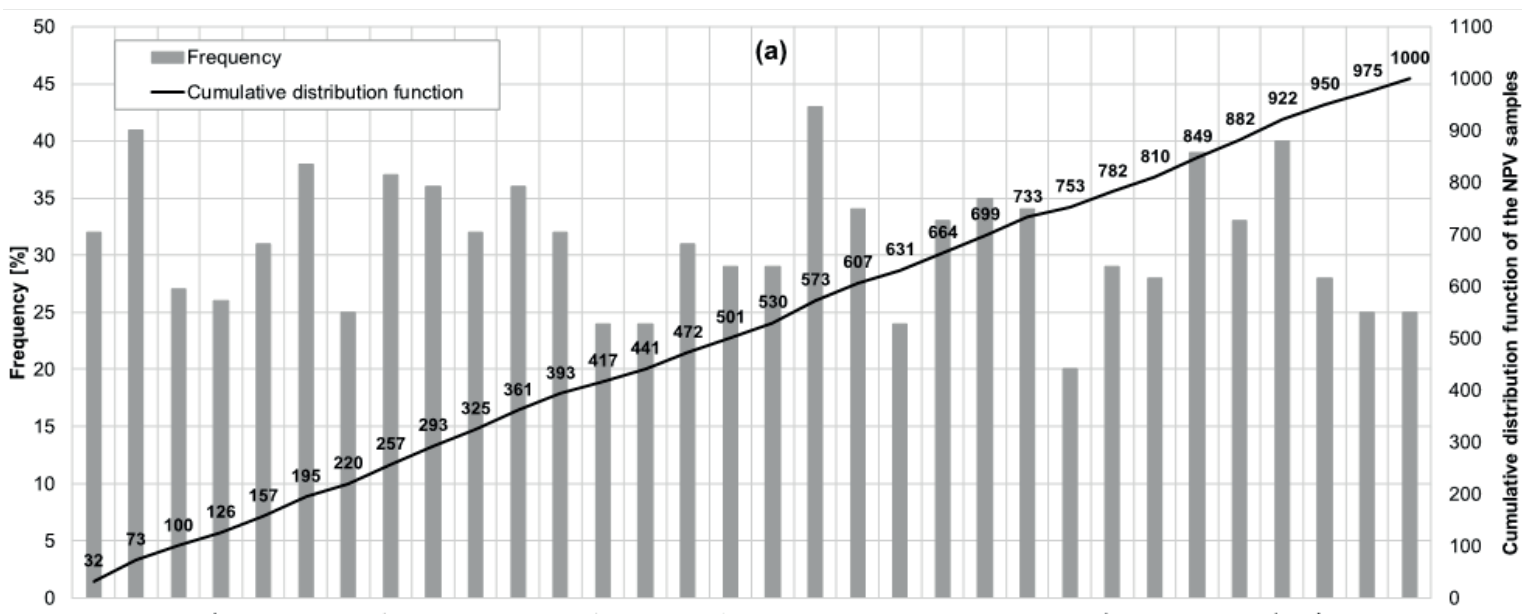

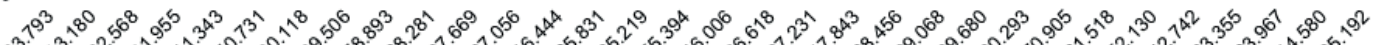

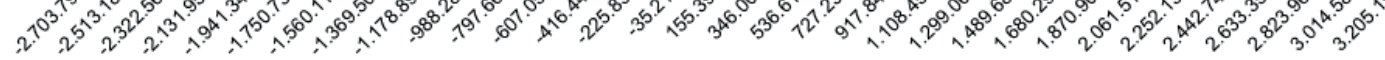

NPV [€]

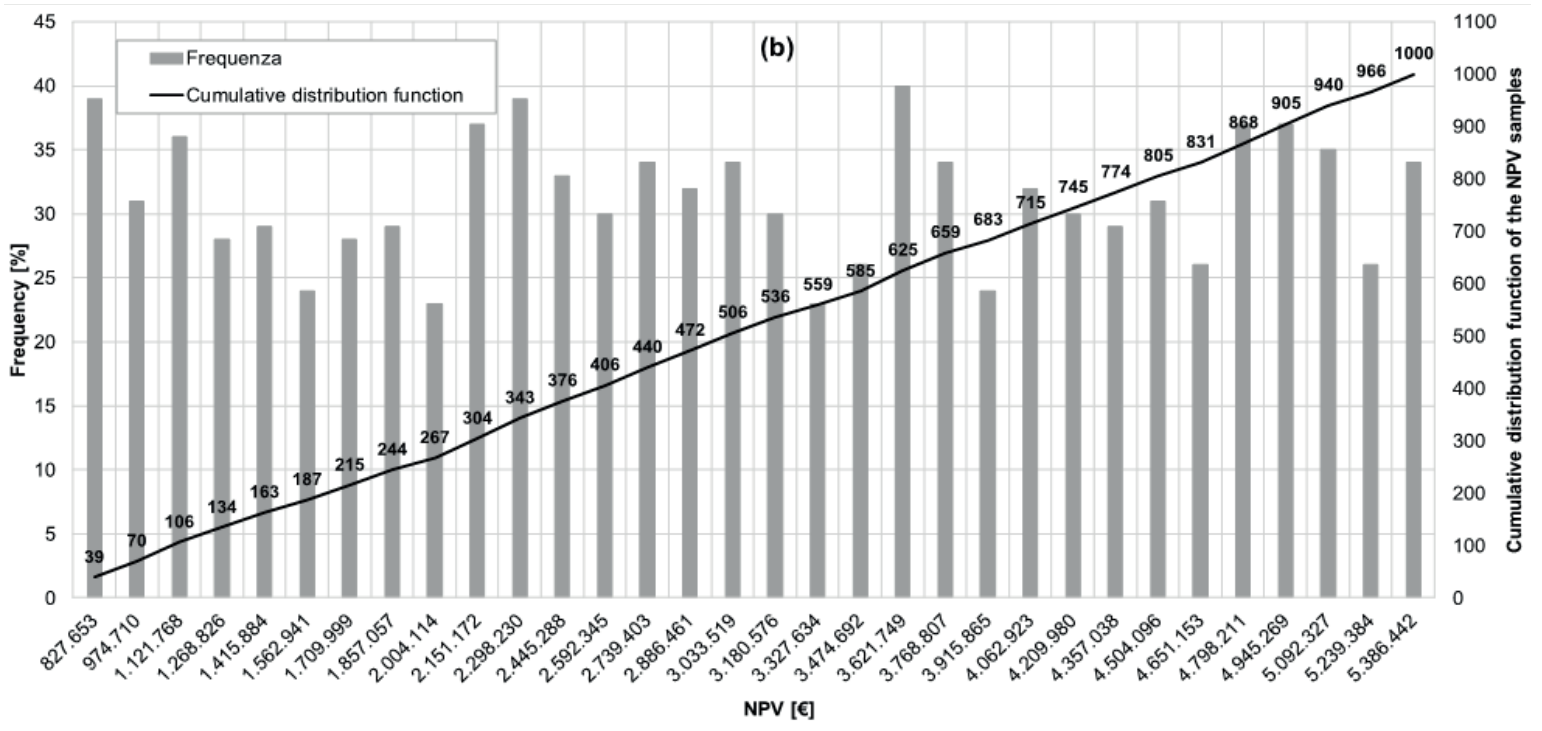

FIGURE 3: SGP influence on the NPV in wet AD (a) and dry batch AD (b) technologies. 
According to this method, the dry AD batch technology may reach $90 \%$ possibility to have a higher economically sustainability than the wet AD one.

\section{CONCLUSIONS}

Dry batch anaerobic digestion technology and conventional wet anaerobic digestion technology were compared for the specific case: $35,000 \mathrm{Mg} /$ year of source sorted organic fraction of municipal solid waste of AISA IMPIANTI S.p.A. (Arezzo, Italy).

The total primary energy indicator resulted worse for the dry batch anaerobic digestion technology in comparison to the wet one, providing a savings of about $21 \%$ less. The results were confirmed by the sensitivity analysis, showing that very high specific gas production values for the dry batch case were necessary to close the gap between the two cases.

In terms of $\mathrm{CO}_{2}$ equivalent emissions, the dry batch anaerobic digestion technology provided a better indicator than the wet anaerobic digestion system. The opposite result was obtained only when high specific gas production values were assumed for wet anaerobic digestion and low specific gas production values were assumed for the dry batch technology.

From an economic perspective, the results indicated a preference for the dry batch technology due to a higher net present value and a shorter period of return of the investment. This finding was also confirmed by a Monte Carlo uncertainty analysis, showing how the dry batch system featured a $90 \%$ possibility of achieving a higher economically sustainability versus the wet technology.

\section{ACKNOWLEDGMENTS}

The subject of this study was originally the topic of Lorenzo Ceccherini's Master Thesis, whose preliminary work is acknowledged.

\section{REFERENCES}

Agenzia Regionale Recupero Risorse S.p.A., 2017. Rifiuti urbani e Raccolte differenziate Regione Toscana - Dati comunali anni dal 1998 al 2017. https://www.arrr.it/dati-comunali

Angelonidi, E., Smith, S.R., 2015. A comparison of wet and dry anaerobic digestion processes for the treatment of municipal solid waste and food waste. Water and Environment Journal 29, 549-557. https://doi.org/10.1111/wej.12130

Blengini, G.A., 2008. Applying LCA to organic waste management in Piedmont, Italy. Management of Environmental Quality: An International Journal 19, 533-549. https://doi. org/10.1108/14777830810894229

Boldrin, A., Hartling, K.R., Laugen, M., Christensen, T.H., 2010. Environmental inventory modelling of the use of compost and peat in growth media preparation. Resources, Conservation and Recycling 54, 1250-1260. https://doi.org/10.1016/j.resconrec.2010.04.003

British Petroleum, 2018. BP Statistical Review of World Energy. https:// www.bp.com/content/dam/bp/business-sites/en/global/corporate/pdfs/energy-economics/statistical-review/bp-stats-review2018-full-report.pdf

Brown, D., Li, Y., 2013. Solid state anaerobic co-digestion of yard waste and food waste for biogas production. Bioresource Technology 127, 275-280. https://doi.org/10.1016/j.biortech.2012.09.081

Campanelli, M., Foladori, P., Vaccari, M., 2013. Consumi elettrici ed efficienza energetica nel trattamento delle acque reflue. Maggioli Editore.
Cecchi, F., Battistoni, P., Pavan, P., Bolzonella, D., Innocenti, L., 2005. Manuali e Linee Guida 13/2005 - Digestione anaerobica della frazione organica dei rifiuti solidi. http://www.isprambiente.gov.it/contentfiles/00003400/3482-manuali-linee-guida-2005.pdf

Chatterjee, B., Mazumder, D., 2016. Anaerobic digestion for the stabilization of the organic fraction of municipal solid waste: A review. Environmental Reviews 24, 426-459. https://doi.org/10.1139/er2015-0077

Colazo, A.B., Sánchez, A., Font, X., Colón, J., 2015. Environmental impact of rejected materials generated in organic fraction of municipal solid waste anaerobic digestion plants: Comparison of wet and dry process layout. Waste Management 43, 84-97. https:// doi.org/10.1016/j.wasman.2015.06.028

D.Lgs 192/2005, 2005. Attuazione della direttiva 2002/91/CE relativa al rendimento energetico nell'edilizia. http://efficienzaenergetica. acs.enea.it/doc/dlgs_192-05.pdf

Daniel-Gromke, J., Liebetrau, J., Denysenko, V., Krebs, C., 2015. Digestion of bio-waste - GHG emissions and mitigation potential. Energy, Sustainability and Society $5,1-12$. https://doi.org/10.1186/ s13705-014-0032-6

Di Lonardo, M.C., Lombardi, F., Gavasci, R., 2012. Characterization of MBT plants input and outputs: A review. Reviews in Environmental Science and Biotechnology 11, 353-363. https://doi.org/10.1007/ s11157-012-9299-2

Di Maria, F., Sordi, A., Micale, C., 2012. Optimization of solid state anaerobic digestion by inoculum recirculation: The case of an existing mechanical biological treatment plant. Applied Energy 97, 462-469.https://doi.org/10.1016/j.apenergy.2011.12.093

EBA, 2017. EBA Statistical Report 2017. Annual Report 68. http:// european-biogas.eu/wp-content/uploads/2017/12/Statistical-report-of-the-European-Biogas-Association-web.pdf

Evangelisti, S., Lettieri, P., Clift, R., Borello, D., 2015. Distributed generation by energy from waste technology: A life cycle perspective. Process Safety and Environmental Protection 93, 161-172. https:// doi.org/10.1016/j.psep.2014.03.008

Fernández, J., Pérez, M., Romero, L.I., 2008. Effect of substrate concentration on dry mesophilic anaerobic digestion of organic fraction of municipal solid waste (OFMSW). Bioresource Technology 99, 6075-6080. https://doi.org/10.1016/j.biortech.2007.12.048

Forster-Carneiro, T., Pérez, M., Romero, L.I., 2008. Influence of total solid and inoculum contents on performance of anaerobic reactors treating food waste. Bioresource Technology 99, 6994-7002. https://doi.org/10.1016/j.biortech.2008.01.018

Friedrich, E., Trois, C., 2016. Current and future greenhouse gas (GHG) emissions from the management of municipal solid waste in the eThekwini Municipality - South Africa. Journal of Cleaner Production 112, 4071-4083. https://doi.org/10.1016/j.jclepro.2015.05.118

GME - Gestore Mercati Energetici, 2018. Mercati del gas. https://www. mercatoelettrico.org/It/Statistiche/Gas/StatMGP-GAS.aspx

Gunatilake, S.K., 2016. Get Energy from Waste. Lambert Academic Publishing.

IPCC, 2014. Climate Change 2014: Synthesis Report. Contribution of Working Groups I, II and III to the Fifth Assessment Report of the Intergovernmental Panel on Climate Change 151. https://www. ipcc.ch/site/assets/uploads/2018/05/SYR_AR5_FINAL_full_ wcover.pdf

IPPC, 2006. Best Available Techniques for the Waste Treatments Industries. European Commision. http://eippcb.jrc.ec.europa.eu/ reference/BREF/wt_bref_0806.pdf

ISPRA, 2018. Istituto Superiore per la Protezione e la Ricerca Ambientale - Fattori di emissione atmosferica di gas a effetto serra e altri gas nel settore elettrico. http://www.isprambiente.gov.it/ files2018/pubblicazioni/rapporti/R_280_18_Emissioni_Settore_ Elettrico.pdf

ISPRA, 2017. Istituto Superiore per la Protezione e la Ricerca Ambientale - Rapporto Rifiuti Urbani 2017. http://www.isprambiente. gov.it/files2017/pubblicazioni/rapporto/RapportoRifiutiUrbani_ Ed.2017_n.272_Vers.Integrale_rev08_02_2018.pdf

Khoshnevisan, B., Tsapekos, P., Alvarado-Morales, M., Rafiee, S., Tabatabaei, M., Angelidaki, I., 2018. Life cycle assessment of different strategies for energy and nutrient recovery from source sorted organic fraction of household waste. Journal of Cleaner Production 180, 360-374. https://doi.org/10.1016/j.jclepro.2018.01.198 
Luning, L., van Zundert, E.H.M., Brinkmann, A.J.F., 2003. Comparison of dry and wet digestion for solid waste. Water Science \& Technology 48, 15-20. https://doi.org/10.2166/wst.2003.0210

Marchi, M., Pulselli, F.M., Mangiavacchi, S., Menghetti, F., Marchettini, N., Bastianoni, S., 2017. The greenhouse gas inventory as a tool for planning integrated waste management systems: a case study in central Italy. Journal of Cleaner Production 142, 351-359. https:// doi.org/10.1016/j.jclepro.2016.05.035

Masotti, L., 2011. Depurazione delle acque. Tecniche ed impianti per i trattamento delle acque di rifiuto. Calderini.

Mata-Alvarez, J., 2002. Biomethanization of the organic fraction of municipal solid wastes. Iwa Publishing. https://doi. org/10.2166/9781780402994

Mata-Alvarez, J., Dosta, J., Romero-Güiza, M.S., Fonoll, X., Peces, M., Astals, S., 2014. A critical review on anaerobic co-digestion achievements between 2010 and 2013. Renewable and Sustainable Energy Reviews 36, 412-427. https://doi.org/10.1016/j. rser.2014.04.039

Micolucci, F., Gottardo, M., Pavan, P., Cavinato, C., Bolzonella, D., 2018 Pilot scale comparison of single and double-stage thermophilic anaerobic digestion of food waste. Journal of Cleaner Production 171, 1376-1385. https://doi.org/10.1016/j.jclepro.2017.10.080

Ministero delle Infrastrutture e dei Trasporti, 2009. Costo chilometrico medio relativo al consumo di gasolio delle imprese di autotrasporto per conto terzi. http://www.mit.gov.it/mit/mop_all.php?p_ $\mathrm{id}=10640$

Ministero dello Sviluppo Economico, 2018. Decreto interministeriale 2 marzo 2018 - Promozione dell'uso del biometano nel settore dei trasporti. https://www.mise.gov.it/images/stories/normativa/DMbiometano-2-marzo_2018_FINALE.pdf

Nagao, N., Tajima, N., Kawai, M., Niwa, C., Kurosawa, N., Matsuyama, T., Yusoff, F.M., Toda, T., 2012. Maximum organic loading rate for the single-stage wet anaerobic digestion of food waste. Bioresource Technology 118, 210-218. https://doi.org/10.1016/j. biortech.2012.05.045

Neri, E., Passarini, F., Cespi, D., Zoffoli, F., Vassura, I., 2018. Sustainability of a bio-waste treatment plant: Impact evolution resulting from technological improvements. Journal of Cleaner Production 171, 1006-1019. https://doi.org/10.1016/j.jclepro.2017.10.082

Oldfield, T.L., White, E., Holden, N.M., 2016. An environmental analysis of options for utilising wasted food and food residue. Journal of Environmental Management 183, 826-835. https://doi. org/10.1016/j.jenvman.2016.09.035
Patinvoh, R.J., 2017. Biological pretreatment and dry digestion processes for biogas production. Thesis of the degree of Doctor of Philosophy at the University of Borås. https://hb.diva-portal.org/ smash/get/diva2:1141448/FULLTEXT01.pdf

Qian, M.Y., Li, R.H., Li, J., Wedwitschka, H., Nelles, M., Stinner, W., Zhou, H.J., 2016. Industrial scale garage-type dry fermentation of municipal solid waste to biogas. Bioresource Technology 217, 82-89. https://doi.org/10.1016/j.biortech.2016.02.076

Ren, Y., Yu, M., Wu, C., Wang, Q., Gao, M., Huang, Q., Liu, Y., 2018. A comprehensive review on food waste anaerobic digestion: Research updates and tendencies. Bioresource Technology 247, 10691076. https://doi.org/10.1016/j.biortech.2017.09.109

Righi, S., Oliviero, L., Pedrini, M., Buscaroli, A., Della Casa, C., 2013. Life Cycle Assessment of management systems for sewage sludge and food waste: Centralized and decentralized approaches. Journal of Cleaner Production 44, 8-17. https://doi.org/10.1016/j.jclepro.2012.12.004

Saer, A., Lansing, S., Davitt, N.H., Graves, R.E., 2013. Life cycle assessment of a food waste composting system: Environmental impact hotspots. Journal of Cleaner Production 52, 234-244. https://doi. org/10.1016/j.jclepro.2013.03.022

Sullivan, W.G., Wicks, E.M., Koelling, C.P., 2014. Engineering Economy, 16 th ed. Pearson.

Sun, Q., Li, H., Yan, J., Liu, L., Yu, Z., Yu, X., 2015. Selection of appropriate biogas upgrading technology-a review of biogas cleaning, upgrading and utilisation. Renewable and Sustainable Energy Reviews 51, 521-532. https://doi.org/10.1016/j.rser.2015.06.029

Torretta, V., Ionescu, G., Raboni, M., Merler, G., 2014. The mass and energy balance of an integrated solution for municipal solid waste treatment. WIT Transactions on Ecology and the Environment 180 151-161. https://doi.org/10.2495/WM140131

Wernet, G., Bauer, C., Steubing, B., Reinhard, J., Moreno-Ruiz, E., Weidema, B., 2016. The ecoinvent database version 3 (part I): overview and methodology. The International Journal of Life Cycle Assessment 3, 1218-1230. https://doi.org/10.1007/s11367-016-1087-8

Wiedmann, T.O., Minx, J., 2007. A definition of 'carbon footprint'. In: Pertsova, C. (Ed.), Ecological Economics Research Trends, Nova Science Publishers, pp. 1-11.

Zhang, Y., Banks, C.J., 2013. Impact of different particle size distributions on anaerobic digestion of the organic fraction of municipal solid waste. Waste Management 33, 297-307. https://doi. org/10.1016/j.wasman.2012.09.024 